\title{
Ahmet Hamdi Tanpınar'ın Poetikasında Ölüm İmgeleri
}

\author{
TOLGA BAYINDIR*
}

\begin{abstract}
ÖZ
Bu çalışmada, Ahmet Hamdi Tanpınar'ın edebî eserleri temel alınarak, onun “ölüm” kavramı üzerindeki düşüncelerini yansıtan yazınsal imgeleri üzerinde durulmuştur. Tanpınar'da ölüm, hayatının trajik yanlarını ortaya koyan, onun düşüncelerini derinden etkileyen felsefî bir problemdir. Bir sanatçı ruhuyla ölümlü oluşunun farkındalığı, buna rağmen eserleri vasıtasıyla mazi, toplum ve kültürle ölümsüzlüğü isteyişi/arayışı temel çatışma noktalarından birisini oluşturur. Tanpınar'ın özellikle günlükleri incelendiğinde görülecektir ki, ölüm/ölümlü olma ve ölümsüzlük onun yaratma eyleminin altında yatan en önemli unsurlardan birisidir. Bu durum karşısında Tanpınar, eserlerinde kaçınılmaz olarak bilinçli veya bilinçaltı ölüme dair imgeler kullanmaktadır. Ölümün kesin bir tanımının olmayışı, bu konuda düşünen herkes için farklı bir anlamlandırmanın doğmasına neden olmaktadır. Tanpınar insan, sanatçı, toplum adamı olarak ölümü kendisince yorumlamış ve bu edinimlerini eserlerine yansıtmıştır. Bu imgeler, farklı eserlerinde benzer kullanımlar ve eşanlamlarla karşımıza çıkar. Bu çalışma, Tanpınar’ın kullandığı imgelerden belli başlıları seçilerek örneklendirilmiştir.
\end{abstract}

Anahtar sözcükler: Türk şiiri, Ahmet Hamdi Tanpınar, ölüm, imge, metafor

B ilinçli bir varlık olarak insan, hem hatıralarıyla birlikte maziyi yaşama,

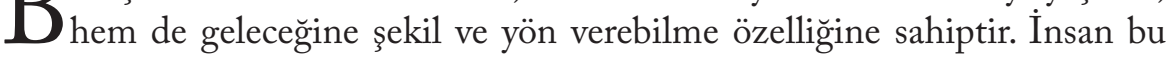
nedenle "ölüm" kavramı ve olgusunu daima hafızasında canlı tutar ve düşünür. Her durum ve şartta ona karşı vaziyet alır, onun için birtakım hazırlıklar yapar ve onunla ilgili inançlara sahip çıkar. İnsanoğlu, bir şekilde kendi sonu-

"Okutman, Kocaeli Üniversitesi, Türk Dili Birimi/KOCAELİ

e-posta: tlgbayindir@hotmail.com 
nu düşünürken ölümle ilgili bazı anlayışlar ve kabullenmeler geliştirebilir. İnsan, içinde bulunduğu sosyo-kültürel yaşam ve kendisini çevreleyen tabiatın ürettiği zihinsel uyaranlar vasıtasıyla ölümü daha sık, daha derin bir şekilde düşünebilir. Buna rağmen ölüm, yaşayan insanlar için tecrübe edilebilecek bir olgu ve durum değil, tam aksine düşünsel temelde yaşanan bir deneyimdir “İyi olup olmayacağını bilmiyoruz ölümün” (Maurois 1961: 162) çünkü ölüm bizim dışımızda vardır. Ahmet Hamdi Tanpınar, Huzur'da bu durumu şu şekilde ifade etmektedir: “'Evet, insanî tecrübe, insanın dışında...' diye tekrarladı. Bunun gibi güzel, mutlak, mesut ve yüksek her şey insanın dışındaydı. Derin düşünce hepsini inkâr ediyordu. Derin ve sağlam düşünce, bir tek noktaya bakardı; Ölüm! Veya başıboş çılgınlık yani hayat!" (Tanpınar 2002: 316)

Tarih boyunca ölümsüzlüğü arayan insanoğlu, bu emeline ulaşamamıştır; çünkü hayatın tecrübe edilmiş kanunları, kaçınılmaz bir şekilde ölümü zorunlu kılmaktadır. Eğer ki ölüm denen algı olmasaydı, yaşam da olmazdı. Ölüm pratiği, Irvin Yalom'da, "hiç ayrılmadığımız karanlık gölgemiz" (2008: 7) ve "endişelerimizin, streslerimizin ve çatı̧malarımızın kaynă̆ı" (2008: 16), Mevlâna'da ise "İnsanın kendi bâtınını görmesi ve âmeli ile karşı karşıya gelmesi” (Kocatürk 1981: 32) şeklinde ifade bulur. Bunun yanı sıra, Paul Gilson’un "Ölüm gülümsüyor arasında mimozaların” (1986: 88), Yahya Kemal Beyatlı'nın "Ölüm âsude bahar ülkesidir bir rinde" (2011: 54), Ivan Soll'un "Ölüm varoluşumuzu karartır ve yarattığı sürekli tehdit o denli dayanılmazdır ki, onu kaçınılmaz olarak bastırmaya yöneliriz" (Malpas, Solomon 2006: 53), Carl Jung'un "Hedefine yol alan bir mermi gibi, yaşam ölümde son bulur" (1992: 9) ve Ömer Hayyam'ın "Ben de geçtim gittim/bu zulüm yurdundan/Elimde yelden başka bir şey kalmadan/Ama var mı ölümüme sevinip de/Ecelin şaşmaz tuzağından kurtulan” (2009: 49) şeklindeki ilgi çekici ifadeleri de ölüme farklı bakış açıları getirirler. Bununla beraber, ölümü tanımlamak olanaksızdır; ölüm kesin boşluğu, var olmamayı ve hiçliği temsil eder. Tanpınar da "Hakikî fert için ölüm hiçliktir. Hiçliğin vasfı olamaz" (2000: 22) cümleleriyle bu durumu ifade eder. Ölüm, varlığın ötesinde, iletişimin mümkün olmadığı bir yerdedir; çünkü ölüme uygun bir anlam yükleyip ona hâkim olma girişimi hiçbir zaman sonuç vermez.

Ölüm olgusu, insanoğlunun psikolojik ve kültürel tarihinde karşılaşılacak en önemli arketiplerden biridir. Ölüm, varoluşun temelinde insanoğlu için doğumundan itibaren tek gerçektir; ama aynı zamanda var olamama tehdidini de içermektedir. Bu durum, ölümden kaçamayacağının bilincinde olan insan için bir "kaygı" kaynağıdır. İnsanlık tarihi bu kaygıyı hafifletecek kültürel, sanatsal, edebî, dinî aktiviteler ve sembollerle ölümü bastırma uğraşlarıyla doludur. Toplum kavramı, bu yadsımanın hafifletildiği en dinamik oluşum olarak karşımıza çıkar: "Başkalarının hayatta kalması söz konusu olmadığı sürece, 
bireyin hayatta kalmasının hiçbir anlamı ve çekiciliği yoktur" (Bauman 2000: 55). Tanpınar'ın eserleri okunduğunda görülecektir ki, onda "toplum" olarak adlandırılan yapı ebedîdir. Bu nedenle toplum, devama mecburdur. Tanpınar, toplumun bireyden önce geldiğini düşünür. Bu sayede insan düşüncesi kendi ölümsüzlüğüne ulaşabilir:

Fert hayatının yerine, topluluk hayatını koyduğumuz an, ölüm bizim
için hiçbir hoyrat tarafı kalmamış bir tecrübe olur. 'Ben bu çınarda
milyonlarca yaprağın arasında bir yaprağım. Mesele benim devamım
değil bu çınarın devamıdır. O devam ettikçe ben devam etmiş olaca-
ğım. Sonsuz zaman içinde onun vakarlı gövdesinin yükseldiğini bil-
mek benim için yetişir. Milyonlarca kuş her akşam onda toplanacak,
her sabah şafakla oradan geniş mekânı fethe uçacak. Mevsimler deği-
şecek, devirler geçecek; fakat o daima kendisi kalacak. Başı muzaffer
aydınllkta yüzecek; kökü karışı ağlarılyla toprağın derinliklerini yok-
layacak. Firtına, yıldırım, her şey onu deneyecek; fakat o daima zama-
nın ve mekânın hakimi kalacak...' Bunu diyen ruh ölümü bir hamlede
yenmiş olan ruhtur. (Tanpınar 2000: 93)

Devamlılığa mecbur olan Tanpınar'ın "çınar" olarak simgeleştirdiği işte bu yapıdır; yani "toplum"dur. Zaman denilen "mefhum" çalıştıkça bu çınardan düşen her yaprağın yerine mutlaka bir başkası gelecektir. Bu durum, insan kaderinin son ve en büyük parçasıdır. Toplum ve kültür hayatının devam etmesi, zamana karşı insanoğlunun tek zaferi gibi görülmektedir.

Tanpınar, romanlarında, hikâyelerinde, denemelerinde özellikle de şiirlerinde ölüm imgesini bilinçli olarak kullanmış bir sanatkârdır. Ölüme dair düşüncelerini/hayallerini birçok eserinde farklı şekillerde dile getirmiştir. Bu çalışmanın amacı, bu düşünsel metaları ortaya koymak değil; bunların bütünündeki ortak imgesel değerleri tespite çalı̧maktır. Söz konusu imge olunca doğal olarak Tanpınar'ın şiirleri temel alınacaktır. Bununla birlikte şiirlerindekine paralel diğer edebî eserlerindeki ölüm imgeleri de örnekleriyle açıklanmaya çalışılacaktır. Eğretileme, her dilde, sözcük aktarmasının en yaygın türlerinden biridir. Metafor terimine karş1lı gelen, Yunanca "metaphora", Fransizca "mètaphore", İngilizce "metaphor", Almanca "Metapher" biçiminde kullanılan deyim aktarması, Türkçede istiare terimiyle çok uzun süre kullanılmıştır (Aksan 1998: 62). Edebiyat, malzemesi dil olan ve bu araci en derin manalarda kullanan bir sanattır. Sözcüklerin yazınsal değeri, metnin bütününe şekil veren anlam yükleridir.

\section{Perde}

Tanpınar, hayat ve ölüm tezadını şiirlerinde sıkça işlemiştir. Şair, ölüm duygusunun kayg1 verici yüzüyle karşılaştı̆̆ durumlarda, genellikle rüya âlemine dalmaktadır. Bu dünya ile Tanpınar'ın yarattı̆̆ı bu rüya dünyasını ayıran ise, 
eserlerinde perde imgesi olarak karşımıza çıkar: "Perde, görüşü, ışığ1 engellemek veya bir şeyi gizlemek için bir açılı̆ğın önüne gerilen örtü” (Parlatır 1998: 1790). Bununla birlikte, Tanpınar'da ifadesini bulan perdenin biraz daha saydam bir özellik gösterdiği açıktır. Burada mecaz anlamda kullanılan perdenin, daha çok bir "tül perde"yle kıyaslanması doğru olur.

Ölüm bağlamında perdenin Tanpınar'daki derin manasını anlamak için, Sabnenin Dışındakiler'de Cemal'in şu sözlerine yer vermek yerinde olacaktır:

Şunu da söyleyeyim ki bütün acılar, hatırlamalar ve düşünceler, kuvvetlerini arttıran alkolün, benimle etrafım arasında gerdiği tül kadar ince, fakat bir türlü delinip öbür tarafina geçilmesi kabil olmayan bir perdenin, bir nevi şeffaf zarın arkasında oluyordu.

Etrafımızdaki her şeyi onun arasından görüyor ve onun arkasından belki de başkaları için kaybolmuş gibi yaşadığımı sanıyordum.

$\mathrm{Bu}$ duygumla kendi kendime 'belki de ölüm dediğimiz şey böyledir. Tül kadar ince ve bulanık bir zarın arkasında gizlenmek, oradan etrafı dinlemek, görmek, oradan sevdiklerine hasret çekmektir' diyordum. (Tanpinar 1999: 179)

Ölümün perde gibi, ince bir zar veya tül motifiyle somutlanması Tanpınar'ın hemen bütün eserlerinde karşımıza çıkar: "Bazı anlarında Nuran, karşısında iken kendi hayatından çekilmiş görünebiliyordu. Ve bu hâl genç adamda, kendi ruh hâllerine göre onu bir ölümün perdesi arkasından veya unutulmuş olmanın araya koyduğu uzaklıklardan seyrediyormuş zannını uyandırıyordu” (2002: 205). Huzur'un bir başka bölümünde ise şu şekilde karşımıza çıkar: “ 'Ne olurum?' diye bir dakika düşündü. Muhakkak ki dünya ile arasında şimdiye kadar tanımadığı bir perde vardı. Çok şeffaf, son derecede vuzuh getirici bir şey onu dünyadan böyle ayırıyordu” (2002: 384). Böylece, perdenin öbür tarafına geçmek istememenin, zihin tarafından üretildiği daha iyi anlaşılmaktadır; çünkü Tanpınar'da ölüm korkunç bir olay olarak görülmez. Var olduğunu düşündüğü bu perde, hayatın içinde iki dünyayı birbirinden ayırır; fakat Tanpınar, bu perde insanı gerçekten "dünyadan ayırabilir miydi?” sorusunu sorduktan sonra şu açıklamayı getirir:

Hayat o kadar güzel ki... Hakikaten bu sabah saatinde yaşamak güzel şeydi. Her şey güzeldi, taze ve ahenkliydi. Bir gülüşün yumuşaklı̆̆gyla insana geliyordu ve Mümtaz bir akasya yaprağına, bir küçük hayvan yüzüne, bir insan eline bu saatte bikmadan ebediyet boyunca bakabileceğini sanıyordu. Çünkü hepsi, her şey güzeldi. Bu belirsiz ş̧ık bir senfoniydi; işte camiin avlusunda ilk huzme bir kadın gibi soyunmuş oynuyordu. Bu taze simit kokusu, yürüyen adamların acelesi, bu düşünceli yüzler hepsi güzeldi. Fakat hiçbirinin üzerinde duramıyordu. Böyle bir saatte? Belki de eşyayı bu kadar güzel bulduğum için hayattan boşanmış olabilirim. Niçin olmasın? (2002: 384) 
Beş Şehirde perde imgesi, "Bursa'da Zaman" başlıklı bölümde özellikle tarihî bir miras olan türbelerden bahsedilirken karşımıza çıkar: "[T]ürbe ve buna benzer yerlerde yatanlar için perdenin arka tarafi, şüphesiz ki sadece tatlı bir uyuşukluk içinde kaybedilmiş nimetlerin hasreti duyulan bir rüyadan ibarettir" (2006a: 105). Ölüm ile hayat Tanpınar'da birbirine o kadar yakındır ki, bu iki olgu arasında sadece ince bir örtü bulunmaktadır. "Ey Kartal Bakışlı" başlıklı şiirinde ise ölüm, bu perdeyi yırtan ve varlığın sonunu getiren bir olaydır: "Ey kartal bakışlı avcısı fecrin,/Açmamış güllerin siyah bahçesi;/ Büyük hasatçısı serviliklerin,/Varlığın perdeyi yırtan gölgesi” (2009b: 53).

Aydaki Kadın'da da ölüm, hayatın yanı başında, insanı kat kat örten bir perdedir: "Ben kat kat perdelerin, muvazaaların arasında yaşayan bir biçareyim" (2009a: 232). İnsanı, hayatı kaplayan bu perdenin yırtılması veya kopmas1 Huzur'da bir son ve kurtuluş olarak karşımıza çıkar:

Son... kurtuluş her şeyin bitmesi ve perdenin inmesi. O büyük ve ferahlatıı boşanma. Bütün kafasındakilere, hepsine birden 'Paydos!' demek, kapiları açmak ve yol vermek, son zerresine kadar her hâtırayı, her hayali, her tasavvuru kovmak ve herhangi bir nesne, cansız ve şuursuz bir mevcut olmak, bu güneş altında parlak bir yılan sırtı gibi, bir ucu dikilen sokağa, güneşin yer yer bir cüzam gibi kemirdiği duvarlara, evlere katılmak, varlı̆̆ı çemberinden çıkmak, bütün tenakuzlarından kurtulmak... (2002: 64)

Bu düşünceler bizi aynı zamanda daha önce bahsettiğimiz, ölümle hayatın iç içe olması konusuna götürmektedir. Abdullah Efendinin Rüyalarinda da bir rüya hali olarak perde, hayatı çerçeveleyen bir anlam kazanır. Kahramanın "[b]ütün etrafiyla kendi arasında imkânsız denebilecek derecede kuvvetli bir münasebet teşekkül etmişti” (2006b: 21-22). Bu münasebet, "bir yığın perde" (2006b: 22) ifadesiyle anlamlandırılır. Tanpınar, ölümü hayata o kadar yakın görür ki, ölüm denen bilinmezlikten, perdenin arkasında yine bu hayatı görebiliriz. Bize acı verecek olan ise sevdiklerimizden (iletişimden) ayrı kalmak ve hasret çekmektir. Burada dikkat edilecek en büyük özellik ise, perdenin arkasında -ölümde- yine var olma durumudur. Bu da bize, Tanpınar'ın ölümü bir yok oluş gibi görmediğini düşündürmektedir; çünkü ona göre, insan için asil mutluluk kendisini idrak edebilmesindedir:

Sonunu bile bile ve o sona rağmen, kendisini idrak etmek... Basit bir jest değil mi? Kollarımı göğsümün üzerinde kavuşturuyorum. Adalelerimi yokluyorum. Basit bir şey. Fakat bütün ölüm çarkına rağmen kendimi ikrar ettim. Varım, diyorum; fakat yarın olmayabilirim... Fakat şu dakikada varım... Varız, varlığı sevebiliyor musun? Uzviyetine dua edebiliyor musun? Ey gözüm, ey burnum, ey kollarım, karanlık ve aydınlklarım... size şükrediyorum, bu dakikanın sarayında, bu ânın mucizesinde beraberce varolduğumuz için; sizinle bir andan öbürüne geçebildiğim için; anları birleştirip düz ve yekpare zaman kurabildiğim için! (2006b: 239) 
Tanpınar'da bir birey olarak insanın kendini gerçekleştirebiliyor olması, aynı zamanda onun yaşamı anlamlandırmasının da anahtarıdır.

\section{Kartal}

Eski Mezopotamya uygarlığında ruhun devamı düşüncesi hâkimdir. Babilliler bedenden ayrılan ruhun, kartal ya da kuş biçiminde göğe yükseldiğine inanmışlardır. Bununla birlikte eski Türklerde de uçmak ve kuş motifleri, farklı yollarla ruh ve ölüm olarak algılanmıştır:

Modern etnografik araştırmalar, Türk topluluklarında ruhun dünyada bir insan bedeninde tecessüt etmeden önce, gökte kuş şeklinde ikamet ettiğinin tasavvur edildiğini ortaya koymaktadırlar. Orhun Kitabeleri'nde Bilge Kağan ve Kültigin için uçtu tabiri yer almaktadır. Kağan ve beylerin ölümü halinde ruhlarının bir kuş gibi uçarak göğe, Tanrı'nın yanına gittiğine inanılmaktaydı. (Günay, Güngör 2003: 70-71)

Tanpınar'ın özellikle şiirlerinde kartal, atmaca veya kuş imgelerini kullanarak ölüm fenomeniyle bağlantı kurduğu söylenebilir. Bu tarz şiirlerinde kapalı ve karanlık bir atmosferin hâkimiyeti ile akşam, karanlık, batan güneş, gece ve sonbahar imgeleri kullanılmıştır. Bunun nedeni, insanın sonluluğuna veya ölümlülüğüne dair kayg1 uyandıran duyguların ifadesini bulma arzusudur. "Bendedir Korkusu" adlı şiirinde Tanpınar, tükenen ömrün ıstırabını: "Bendedir korkusu biten şeylerin" (2009b: 23) mısratyla ifade eder; çünkü ona korku veren unsur bitmek/tükenmek eylemlerinde kendisini gösterir. Aynı bağlamda, geçen ve biten zaman, yani tükenen ömür de sonlu oluşun kayg1sını uyandıracaktır. Bir kartalın pençesinde asılı olan hayatı, zamanın hızla tükettiğini ve sonsuzluk özlemi içinde erittiğini şiirin devamında şu şekilde belirtir: "Çelik gagasında fecri taşıyan/Mavi kartal benim.../Pençelerimde/ Asılmış bir zümrüt gibidir hayat/Sonsuzluk ısırır güzel kavsimde/Susamı̧̧ bir ceylan gibi zaman!" (2009b: 23)

Her insan gibi Tanpınar da yaşama bağlıdır; fakat ölümlülüğünün bilincinde olması nedeniyle belirgin bir rahatsızlık duymaktadır. "Ey Kartal Bakışlı" başlıklı şiirinde olduğu gibi ölüm, fecrin kartal bakışlı avcısı ve açmamış güllerin siyah bahçesidir: "Ey kartal bakışlı avcısı fecrin,/Açmamış güllerin siyah bahçesi;/Büyük hasatçısı serviliklerin,/ Varlığın perdeyi yırtan gölgesi” (2009b: 53). Şiirde, özellikle mezarlıklarda sıkça görülen servi ağacının da kullanılması, şiirin arka planında ölüm imgelemini ortaya çıkarmaktadır. Burada ölüm, servilerin hasatçısı-toplayıcısı olarak karşımıza çıkar. Tanpınar'a göre, ölüm sonrasında varlık, hayat çemberinin üstüne kurulu perdeyi (ölümü) yırtarak yeni bir dünyaya geçmektedir. Bu durumu, Yunus Balcı, "Tanpınar dinin vadettiği metafizik bir âleme inanmadı̆̆g için, perdenin arkasında kendine yeni bir âlem inşa eder" (2008: 89) diyerek yorumlamıştır. 
Tanpınar'da ölümlü olmanın kaygısı, varlığını sık sık rahatsız eden bir durumdur. "Şiir ve Rüya” başlıklı yazısında, ölüme karşı, "Hiç bir karşı koyma imkânını ve düşüncesini bulamayız" (1998: 33) diyerek, yaşam sürecinde insan için, "Bir uçta ölüm ve azap kartalının pençesinde kıvranıp dururuz" (1998: 33) ifadesiyle ölüm endişesinin kendisini bırakmadığını anlatır. "Başka Bir Yıldızda" adlı şiirinde de insanın ezeli korkusu olan ölümlülük fikrinin uyku, demir pençe, hülya imgeleriyle birleştiği görülmektedir: "Bu lamba ve hülyamıza/Yabanc1 binlerce uyku/Bir demir pençeydi sanki/Içimizde eski korku..." (2009b: 33).

Kartal imgesi, pençe benzetmesiyle "Hicret" adlı şiirde de karşımıza çıkar. Bir savaş halinin anlatıldığı şiirde, Bayburt'un alevler içinde kalışından bahsederken, "Pençesiyle bütün kalpleri burdu/Seyredince yaşlı gözlerle birden/ Alevler içinde kalan Bayburt'u” (2009b: 103) diyerek, kalpleri buran asıl öğenin ölüm olduğunu belirtir. "Eşik" başlıklı şiirinde de ölüm, karşımıza atmaca imgesiyle çıkmaktadır: "Ey hiç şaşmayan göz, büyük atmaca/Gölgesi güneşin üstünde uçan/Dişi kuyruğunda ebedî yılan” (2009b: 64). İnsanın gerçek trajedisini merak eden Zeus'un, kendisini ölümlü kılarak kısa bir süreliğine insanlar arasına katılışını anlatan "İnsanlar Arasında" adlı şiirin sonunda da kartal motifine başvurmuştur. Zeus, pişmanlıkla tanrılara seslenir: "Ey tanrılar, sen ey gök, ey kartalın efendisi.../ Bana yardım et” (2009b: 95).

"Deniz Ufkunda" başl1klı şiirinde ise, kuş imgesinin ölümle bütünleştiği görülmektedir. Bu şiirde, batan güneş, ümitsizlik, akşam havası ve ateş gibi ifade ve tamlamalar ölüme dair karanlık ve ürkütücü bir atmosfer sergilemektedir: "Deniz ufkunda batan güneş/Ve keskin çığlığı kuşların;/Rabbim bu uğultu, bu ateş/Ve bu ümitsiz uçuşların/Doldurduğu akşam havası,/Akşamın mercan dalları gibi/Suda olgunlaşan rüyası..." (2009b: 26).

\section{At}

Tanpınar'ın şiir dünyasında, yaşanılan anın ötesinde, zengin ve renkli bir hayal dünyası vardır. Bu hayal dünyasının temelleri fantastik, mitolojik imgelerle ve rüya halinin yansımalarıla doludur. Bireysel ve toplumsal olarak süregelen arketiplerin, insan geçmişiyle bütünleşerek semboller aracıllğıyla Tanpınar'ın şiirlerinde yer aldığı gözlemlenebilmektedir. Bu sembol ve imgelerin arka planında, derinlerden gelen trajik kaygının ötesine geçme veya üzerine çıkma endişesinin olduğu açıktır. Özellikle "Siyah Atlar” adlışiirde, hayatın yanı başında duran ölümü, siyah at imgesinde bulmak mümkündür: "Saçında gecenin soğuk rüzgârı/Bir gün kapatırsın bu ufukları/Beklersin köşende sessiz ve yorgun/Siyah atlarını son yolculuğun" (2009b: 30). Burada gece, ölümün bir çağrıştırıc1sıdır. Gece, özellikle soğuk oluşu ve beklemek kavramından hareketle yalnızlık olarak düşünülebilir; çünkü ölüm, insanın tek başına gerçekleştirebileceği bir 
durumdur. Öte yandan insan yaşll1ığında, bir köşede ölümü beklerken kendisine sorar: "Ve dersin yavaşça kendi kendine;/Ömrün çemberinden kurtuldum yine" (2009b: 30). "Rıhtımda Uyuyan Gemi” şiirinde olduğu gibi bu şiirde de ölüm yolculuğa benzetilmiş; böylece bunun bir kurtuluş olduğu fikri işlenmiştir. Aynı zamanda kapanan ufuklar ve yaşlılığın getirdiği olası ölümü bekleme düşüncesi de, şiirin ölüm fikri üzerine kurulduğunun göstergesidir.

At imgesinin işlendiği bir diğer şiir ise "Sonbahar"dır. Bu şiirde ölüm, uzaktan geçen bir atlyya benzetilmektedir. İnsanın, ölümü kendisinden uzak olarak düşünmesini de şiirde bulmak mümkündür. Sonbaharın kavramsal olarak ölümle ilişkilendirildiği bir gerçektir. Bunun yanı sıra şiirin başında yas, sis, matem sözcükleriyle karamsar bir hava verilmiştir. Üçüncü kıtanın ilk mısraında “Karşı ormandan geçen atl kim?” (2009b: 101) sorusuyla bir belirsizlik yaratılmıştır. Şair, gördüğü/farkına vardığı atlının ne olduğundan emin değildir. Bunu Antalya’nın denizine sorar: "Deniz, uzaklarda yanan bir şey var.../Ufkun sükûnuna ölüm mü hâkim,/Niçin sustu demin inleyen rüzgar?” (2009b: 101). Ölüm fikrinin belirmesiyle birlikte, gerçeğin de ne olduğu anlaşılacaktır; çünkü karşı ormandan geçen atlı zamandır. Mevsimlerin geçişi aslında ölümün de gelişi olarak yorumlanmıştır. Bu farkındalık, Tanpınar'da vahşet olarak anlamını bulur: "Vahşetle tutuşan gözlerinde kin/Mevsim mi bu geçen yoksa ölüm mü?/Yolunda can veren hüzünlü, bitkin/Bir gölgedir şimdi yaprak dökümü” (2009b: 101).

"Eşik" şiirinde ise Tanpınar, trajik duruşunu açık bir şekilde ortaya koyar. Mehmet Kaplan'a göre bu şiir, şairin iç ile dış arasındaki çelişkisinden bahseder. Tanpınar'in Şiir Dünyası adlı kitabında bu düşüncesini şöyle ifade eder: "Şair, ne tamamiyle dış âleme karşı uyanık, ne de tamamen içine kapalıdır. Hem içine hem dışına bakar" (2001: 128). Gerçek dünya ile şairin yarattı̆̆ı dünya, yani iç ve dış, eşik kelimesiyle karşılı̆̆ını bulmaktadır. Tanpınar'da karanlık-aydınlık, hayat-ölüm hep iç içedir. Bu onun dış dünyasıyla içindeki trajik unsurların çelişkisidir. Hayat karşısında, tanıdığı güzel imgelerinin sonsuz olmasını ister. Kaplan'a göre bu şiir, Tanpınar'ın genç yaşta kaybettiği annesinin ardından duyduğu hüznün sembolik bir ifadesidir: "Evet çok bekledim, kaç kere hazan/ Dinç atlar koşturdu boş ufuklardan/Yeleler alevli, ağız köpüklü,/Bulutlar bir kanlı hiddetle yüklü" (2009b: 65). Alev, kanlı, at, boş ufuk kelime ve ifadeleri bir arada kullanılarak, ölümün geride kalan insanlar için bir bekleyiş olduğunu ifade edilmiştir. Bununla beraber, Tanpınar'da bu bekleyişin sonu hazandır.

\section{Ejderha}

Tanpınar, 1933'te Güzel Sanatlar Akademisi'nde sanat tarihi hocalı̆̆1 yapmaya başlamıştır. Bundan bir yıl sonra estetik ve mitoloji derslerine de girmiş, böy- 
lece mitoloji ve antik sanatla yakından ilgilenmeye firsat bulmuştur. Ali İhsan Kolcu, bu yakınlaşmanın bir sonucu olarak, Tanpınar'ın yazı ve manzumeleri incelendiğinde, "Zeus, Kronos, Sisypos, Orphèe, Narkinos, Eurydice, Afrodit, Apollon, Atlas, Erinnyes, Dionysos, Pan gibi tanrı ve kahramanların adlarına tesadüf edilir" (2002: 151) demektedir. Özellikle, "İnsanlar Arasında" ve "Bir Heykel İçin" adlı şiirlerinde, bu mitolojik açılımın izlerini bulmak mümkündür. Bununla beraber, bu şiirlerde de ölüm kavramı, trajik duruşunun çıkış noktasını oluşturmaktadır. "İnsanlar Arasında” adlı şiirinde Tanpınar, tanrısal açıdan insan-kader çatışmasını işlemektedir. Geçici bir süre için insan olmayı isteyen Zeus'un gözünden insan olmanın trajik gerçekliğini anlatmaya çalışır. Şiirde Zeus, insanın talihiyle karşılaşmak ve bu durumda ne hissettiğini öğrenmek istemektedir: "Hastalık, açlık, ölüm, ayrılık/Bilinmezden doğru gelen korku, ejderlerin en büyüğ̈̈/Ve simsiyah ihtiyarlıkta o korkunç hatırlama" (2009b: 91). Zeus için ölümün bilinmezliği, onu korku duyulacak en büyük "ejder" kılmaktadır. Burada mitolojik bir yaratık olan ejderha imgesi karşımıza çıkar. Tanpınar'a göre, ölümü getirecek olan ejderhadır. Bundan sonrası, insan için bilinmezliği temsil eder. Zeus'un bilmediği ise ölümlü olma duygusudur. İnsan, ölüm karşısında, ona göre, ümitsiz bir isyan halindedir: "Ümitsiz isyanı tadacağım onların arasında..." (2009b: 92). Yunus Balc1'ya göre bu şiirde, "[i]nsanın ebedîleşme isteği ters yüz edilerek, insanı farklı bir açıdan anlama gayreti gösterilir” (2008: 43). Zeus çok istediği ölümlülüğü tattıktan kısa bir süre sonra, bunun kendisi için bile dayanılmaz bir 1stırap olduğunu anlayarak kendisini yeniden ölümsüz yapmaları için tanrılara yalvarır. Son noktada ölüm, öyle bir trajedidir ki, "Tanrıların bile insan olmaya tahammülü yoktur" (2008: 43).

Tanpınar'ın şiir dünyasında, efsanevi öğeleri ve kültürel arketipleri de bulmak mümkündür. "Bir Heykel İçin" adlı şiirinde, ölümlü olmanın 1stırabını, bir kadın heykelinin ölümsüzlüğüyle anlatırken yine ejderha imgesinden faydalanır: "Hiç akmayan bir zaman nehrinin sularında/Ne uçan bir kırlangıç, ne sedef kumsalında/Ateşler püskürterek dolaşan bir ejderha” (2009b: 31). Burada, ölümlüler arasında duran heykel, zamandan bağımsız bir şekilde "ölümün sonsuzluğu içinden" hayata gülümsemektedir. Onun içinde bulunduğu zamanda, ölümü çağrıştıran ne bir kırlangıç ne de bir ejderha vardır. Buna karşın insan daima ölümlü olacaktır. Kaplan’a göre Tanpınar, sanat aracılığı ile sevdiği şeyleri ebedîleştirme çabasındadır. Bu şiirinde de, "güzellik vasıtasıyla ölümün trajedisini ve sanatın rolünü ortaya koyar” (2001: 72).

Huzur'da ise "ejderha” imgesi, Mümtaz’ın çocukluğuna dair rüyalarının bir parçası olarak karşımıza çıkar. Babası ve annesinin arka arkaya ölümleri, onun çocuk dünyasında farklı imgeler olarak zihninde belirir: "[K]endi çocuk muhayyilesine sığmayan bir yı̆̆ın şey, orada da ölüm, gurbet, kan, yalnızlık ve içinde çöreklenen o yedi başli ejder hüznü” (2002: 35). 


\section{Gemi}

Tanpınar'ın şiir anlayışında Yahya Kemal'in etkisinin olduğu bir gerçektir. Günlüklerinde bu durumu açıkça ortaya koyar: "Hiç kimsenin, Yahya Kemal hariç, tesiri altında kalmadım” (Enginün, Kerman 2008: 332). Yahya Kemal'in "Sessiz Gemi" başlıklı şiirinde, ölüm bir gemiye ve ona bağlı bir yolculuğa benzetilmiştir. Bu açıdan bakıldığında, şiirin sanatsal anlatımdan yararlanarak kişiden kişiye, kültürden kültüre değişiklik gösteren ölüm kavramı üzerine kurulduğu görülebilmektedir. Salim Çonoğlu, Yahya Kemal'i Cumhuriyet dönemi Türk şiirinde, ölüm ve ahiret duygusunu bu dünya ve sonsuzluk âlemi bağlamında işleyen şairler arasında gösterir: "Sonsuzluğu, ufukları, öte ve âhiret duygusunu şiirin ana teması haline getiren şair, bu duyguların yanı sıra bir milletin meydana gelişinde önemli bir vasıta olarak gördüğü dini ve dinin yanı başında ölüm ve âhiret duygusunu da şiirlerinde işlemeyi ihmal etmemiştir" (2007: 81). Şiirin temelinde soyut kavramlarla birlikte okuyucuya olumsuz bir durum sezdirilmektedir. Özellikle "meçhul", "elem", "hicran”, "matem", "nafile" ve "bîçare" kavramları olumsuz bir tavır sergiler. Bunun yanı sıra, "memnun" olanların gemi aracıllğı ile ölüme gidiyor olması, şiirde bir tezat oluştururlar:

Böyle bir durumda da alıcının (okuyucu/dinleyici), olumsuz bir tutum içine çekilmesi doğaldır. Fakat metindeki Asıl kişi, tüm bu olumsuz duyguların dışında; olumsuz bir duruma karşı memnuniyetini de belirtmektedir. Bu memnuniyet zorunluluktan doğmaktadır. Gidenlerin geri dönmemesi güzel bir nedene (memnuniyet) bağlanmaktadır. (İşeri, Demirgüneş 2008: 508)

"Sessiz Gemi"de, bu dünyadan yola çıkarak bilinmeze gidenlerin geri dönmeyişleri, gittikleri yerden hoşnut olmalarıyla izah edilir. Şiirde, yolculuğa çıkanlar arasında bir sessizlik hâkimdir ve bu ölümün sessizliğidir. Geride kalanlar için elem ve kaygı veren unsur, kendi sonlarına dair trajediyle olan karşılaşmalarıdır. Tanpınar'ın "Rıhtımda Uyuyan Gemi” başlıklı şiirinde, hocasının "Sessiz Gemi” şiirinden etkilendiği görülmektedir. Özcan Bayrak’a göre, bu iki şiir “ölüm izleği çerçevesinde çözümlenmektedir” (2008: 39). Her iki şiirde de, sessizlik, rıhtım, demir almak, gidip de gelmeyenler ve bekleyenler ortak öğeler olarak karşımıza çıkar. Bu ögeler her iki şiirde de aynı anlamda kullanılmıştır. Tanpınar'da farklı olarak ölüm, "güzel yolculuk”ta, şafak serinliğinde uykuya dalmaya benzetilmiştir. Bu yolculuk da gemi imgesiyle tamamlanır:

Rihtımda uyuyan gemi

Hatırladın mi engini,

Sert dalgalar1, yosunu,

Suların uğultusunu... 


\begin{abstract}
Nolur bir sabah saati
Çă̆ırsa bizi sonsuzluk.

Birden demir alsa gemi

Başlasa güzel yolculuk.

Yrrtılan yelkenler gibi

Enginle baş başa kalsak

Ve bir şafak serinliği

İçinde uykuya dalsak

Rihtımda uyuyan gemi

Hatırladın mı engini

Gidip de gelmeyenleri

Beyhude bekleyenleri.
\end{abstract}

(2009b: 39)

Yahya Kemal'in "dönmeyecekler" şeklinde anlattığ "sonsuzluk" kavramı Tanpınar'da doğrudan ifadesini bulmuştur. "Sonsuz" olan, her iki şair için de memnuniyet veren, güzel olan anlamsal yükünü taşımaktadır. "Gidip de gelmeyenleri” mısraında ölüme dair çağrışımın değişik bir boyutu bulunmaktadır. Ölüme gidilen yerde, beden olmasa bile ruh varlığını devam ettirmektedir. Ruh orada vardır ama gelmeyendir. "Beyhude bekleyenler" ise bu dünyada elemle kalanlardır. Tanpınar, şiirin arka planına "uyku" motifini de eklemiştir. Huzur'da "uyku ölümün kardeşidir" (2002: 366) şeklinde ifade edilen uyku ve ölüm bağı, bu şiirde de karşımıza çıkar. Yine hikâyelerinde de aynı konuya şu cümleyle değinmektedir: "Eskilerin 'ölümün kardeşi' diye anlattıkları uyku beni bir tarafımdan yakalamış” (2006b: 69).

"Bir Gül Tazeliği” başlıklı şiirinde ise, geçen günler insanın elinden uçan kuşlardır ve şair hayatın sahilinden, insanın mutlak kaderine bakmaktadır. Şiirin arka planında ise akşamın karanlı̆̆ı, yosun bahçeleri ve bulutların solgun menekşe rengi, ölümün birer çağrıştırıcısıdır. Gemi, dönmemenin imkânsızlığı içinde, sahilde insan kaderini tamamlamayı beklemektedir: "Kaç akşam seyrettim bu sahilde ben/[...]/İmkânsız sularda tutuşan gemi,/Uçan güvercinler avucumuzdan/Ayrilmayan kader baş ucumuzdan" (2009b: 32).

Kader, gemi ve ölüm bağının kurulduğu bir diğer şiiri ise "Musiki”dir. Tanp1nar için hayat, ölümü çağrıştıran düşüncelerin zalim bir tekrarından ibarettir. "Bir Gül Tazeliği" başlıklı şiirinde "imkânsız" sularda tutulan gemi "Musiki" şiirinde mahur sularda karşımıza çıkar. Bu şiirde, ayrıca siyah ve melek motifleri de ölüm temasına çağrışım yapmaktadır: "Bu çılgın uyanış her düşünceden/Üst üste ve zalim, bir kader gibi,/Bir melek uzanmış siyah geceden/ Mahur sularında tutuştu gemi” (2009b: 43).

"Sis" başlıklı şiirde, bilinmezlik temel konu olarak alınmı̧̧ olsa da, bilinmezliğin arkasında yatan korku gemi imgesiyle bütünleştirilmiştir. Tanpınar, ge- 
çen günlerini, bilinmezin/ölümün üzerine doğru gelişine benzetmektedir. Bu bekleyişin sonucunda gemi, korku ve siyah imgeleri şiirde bir arada kullanılmıştır: "Geliyor hepsi, her şey simsiyah bir gemi/Geliyor korku denizlerinden/Üstümüze doğru/Ve durmadan arıyor bir kıyamet telâşında/Vapur düdükleri can kurtaran seslerini” (2009b: 135).

"Selam Olsun" başlıklı şiirinde Tanpınar, hayata ölmüş bir insanın gözünden bakmaktadır. Yaşama dair unsurlar, bu şiirde özlem duyulan birer nesne olarak karşımıza çıkar. Şair, özlem duyduğu bu unsurları, gül, güneş, ay, 1şık, gölge, tipi, firtına ve kuş olarak sıralar; fakat artık bunlardan uzaktadır. Ölüm ise dönmeyecek olan bir gemidir. Tanpınar'ı kaygılandıran ölüm değil, ölümünden sonra adının hatırlanıp hatırlanmayacağıdır: "Dönmeyen gemiler olduk açıktan/Adımızı soran arayan var mı" (2009b: 28). "Rıhtımda Uyuyan Gemi" başlıklı şiirinde olduğu gibi, bu şiirde de ölümün dönülmezliği ön planda tutulmuştur. Gemi imgesi Aydaki Kadın'da dönülmeyeni şu şekilde ifade eder: "Bu anda Selim kendisini, nereye gittiğini bilmediği bir gemiye tesadüfen binmiş ve onunla beraber dönüş imkânı olmayan bir yolculuğa çıkmış sayabilirdi” (2009a: 62). Tanpınar, 16 Haziran 1961 tarihli günlüğünde ise ölümü bekleyen bir duygu haliyle kendisini "gemi”ye benzetir: "Ben parasızlığın şamandırasında yarı hasta, delik deşik bir gemi gibi suyun son hücumunu bekliyorum" (Enginün, Kerman 2008: 308). Bu satırları yazdıktan yaklaşık altı ay sonra 24 Ocak 1962 'de beklediği son darbe gelecektir.

\section{Yilan}

Yılan, edebî türlerde ve mitolojik eserlerde sıkça karşımıza çıkan sembolik bir hayvandır. Özellikle Gılgamış Destanı'nda Gılgamış’tan ölümsüzlük otunu çalması, yılanın uzun bir yaşam sürmesini açıklayan mitolojik bir göstergedir. Âdem ve Havva hikâyesinde yasak meyveyi yemesi için Havva'yı kandırması ve bu yüzden lanetlenmesi de bir diğer efsanevi özelliğidir. Joseph Campbell ve Bill Moyers'ın Mitolojinin Gücü adlı eserinde, yılana dair bu ve benzeri birçok sembolik değeri bulmak mümkündür. Campbell yılana dair yorumunda şöyle demektedir:

Yaşamın gücü yılanın deri değiştirmesine neden oluyor, tıpkı ayın gölgesinin düşmesi gibi. Ayın yeniden doğmak için gölgesine yaptı̆̆ı gibi, yılan da yeniden doğmak için derisini değiştiriyor. Bunlar birbirine denk semboller. Bazen yılan kendi kuyruğunu yiyen bir çember olarak tasvir edilir. $\mathrm{Bu}$ hayat imgesidir. Hayat yeniden doğmak için birbiri ardına nesiller değiştirir. Y1lan, zaman diyarında bulunan, sürekli olarak ölüm gömleğini üzerinden atan ve yeniden doğan ölümsüz enerjiyi ve bilinci temsil eder. Yaşama bu açıdan baktığınızda gerçekten de dehşetli korkunç bir şeydir. Yllan bünyesinde hayatın hem sihrini hem de dehşetini taşır. (2010: 70) 
Tanpınar, saf düşünceyle ölümü bir tuttuğu "Eşik" şiirinde, yılan için yine mitolojik bir imgeye başvurur: "Ey hiç şaşmayan göz, büyük atmaca/Gölgesi güneşin üstünde uçan/Dişi kuyruğunda ebedî yılan” (2009b: 64).

Tanpınar'ın, bir roman havası içeren "Evin Sahibi" adlı hikâyesinde, hastalık ve ölümün korkutucu yüzüyle karşı karşıya kalan kahraman bir hastane odasındadır; ölmek üzere olan bir hastanın acı bağırışlarından dolayı kendi ölümüne dair düşüncelere dalar ve kısa bir süre sonra da çocukluk anılarına döner. Tanpınar, her ne kadar hikâyedeki mekânı Musul olarak değiştirmişse de, onun "Kerkük Hatıraları" adlı yazısından hareketle, anlatılan olayların aslında bir anı içeriğinde olduğu açıktır: "Abdullah Efendinin Rüyaları'ndaki "Evin Sahibi” adlı hikâyem bu Gülbuy'un macerasının senelerden sonra uyanışıdır” (Enginün vd. 2008: 31). Kerkük'te geçen yıllarının ve orada öğrendiği birçok olayın Tanpınar üzerindeki etkilerini bu hikâyede görmek mümkündür. Özellikle adı geçen Gülbuy Hanımın anlattığı yılan olayı, bu hikâyenin omurgasını oluşturur. "Kerkük Hatıraları"nda bu konuya şu şekilde değinilir:

Çok zengin bir ailenin kızıydı. Güzel bir delikanlı ile nişanlanmıştı. Fakat daha nişanın gecesinde rüyasına giren bir yılan, ona âş̧ı olduğunu, kendi malı telakki ettiğini söylemiş ve evlenmesini men etmişti. Sonra sonra onu rüyalarında çok güzel bir delikanlı olarak görmeye başlamı̧. Bu acayip âşık her defasında maceralarını kimseye söylememesini de tembih edermiş. Nikâh zamanı gelince Gülbuy bu sırrı ev halkına açmaya mecbur kalmış. Bir sabah yatağının altında -çünkü y1lan her sabah onun yastığının altından süzülür gidermiş - yakalamışlar ve öldürmüşler. Hemen arkasından babası, biraz sonra nişanlısı ölmüş, bir kardeşini vurmuşlar ve Gülbuy'un da saraları başlamış ve gözlerinden biri kör olmuş. [...] Şurası var ki, Kerkük'te üçüncü evimizde biz de bir y1lan öldürdük. O sene içinde annem Musul'da tifüsten öldü. (Enginün, Kerman 2008: 30-31)

Tanpınar'ın, Huzur'da da bahsi geçen, annesinin tifüsten ölümü bu hikâyeye farklı bir açıdan girer. Yazarın yaşamına yakından bakıldığında etrafının ölümlerle çevrili olduğu görülecektir. 1916'da Musul'da annesini tifüsten kaybetmesi, "insan talihiyle" ilk defa karşılaşmasına neden olacaktır (Okay 2012: 37). Kahramanın hep bu ölümün gölgesinde şekillenen rüya motifleri, masal öğelerinin de eklenmesiyle daha da zenginleşir. Bu motifler içinde en çok bahsi geçen ise yılandır. Yılana ait hikâyeyi annesinin ölümüyle birleştirerek metne farklı bir boyut kazandırır. Hikâyede bahsedilen yılan, bir imge olarak ölümün kendisidir. Yılana dair olaylar, kahramanın annesinin gençliğinde kendisini rahatsız eden siyah bir yılan görmesiyle başlar. Özellikle rüyalarında kendisini çok rahatsız eden bu hayvana genç kız zamanla alı̧ır ve yakınlaşır. Bir gece onu çok yakışıklı bir delikanlı olarak görür. Bununla birlikte, bu yılanı kalabalık ev halkından kimse görememektedir. Korkuya kapılan 
insanlar çare aramak için genç kızı doktorlara, hocalara götürürler ve hatta değişiklik olsun diye onu İstanbul'a gönderirler. Bunlar sadece geçici rahatlamalar sağlasa da çözüm olmaz. Sonunda kızı tanıdıkları bir ailenin oğluyla evlendirmeye karar verirler, ki bu asıl felaketlerin başlangıcı olur. Yılan, kıza bu evliliği yapmaması konusunda baskı uygular. Kızın kendisine ait olduğunu ve başkasıyla evlenmesi durumunda başına olmadık işlerin geleceğini söyler. Bundan dolayı evlilik bir yıl ertelenir. Düğünden sonra her şey bir süre normal devam eder. Genç çiftin bir çocukları olur. Hikâyenin kahramanı olan bu çocuk, babasını hiç göremez; çünkü babası at üzerinde kurumuş bir dereden geçerken aniden sel gelir ve atı ürküten siyah bir yılan yüzünden adam boğularak can verir. Bu olayı sükûnetle karşılayan ve bir daha hiç konuşamayan tek kişi karısıdır. Kocasından üç sene sonra, o da odasında siyah bir yılanın sokması sonucu hayatını kaybeder. Kızın babası her ne kadar yılanı yakalayıp ateşe atarak öldürmeyi başardıysa $\mathrm{da}$, torununu da alıp İstanbul'a gitmeye karar verdiği gün odasında ölür. Onun da yanında bir yılanın yeni değiştirdiği derisi bulunur. Bundan sonra kahraman, aynı Huzur'un Mümtaz'1 gibi, İstanbul'a akrabalarının yanına tek başına gitmek zorunda kalır. Yaşadığı onca ölümden sonra İstanbul'da yanına yerleştiği teyzesini, bu olaylara karşı kayıtsız bulur: "Hayır, burada her şeye bu kadar basit bir gözle bakan insanların arasında yaşamak bana güç gelecekti. Bunlar için ölüm, hayat, günün her hâdisesi, saadetler ve felâketler o kadar tabiî şeylerdi ki... Halbuki ben bütün bir masalı olan bir adamdım" (2006b: 120). Daha on dört yaşında kendi masal dünyasının ağırlığı altında kalmıştır; çünkü bu masalda herkes ölmektedir:

Şimdi bu sayfaları yazarken hayatımı düşünüyorum ve onun bir ölüm hikâyesinden başka bir şey olmadığını anliyorum. Bütün hayatım boyunca onu yanı başımda gördüm. Saatlerimi karanlık bir kumaş gibi o dokudu, çocukluğumu usta bir kuyumcu gibi o işledi, gençliğimi bir mimar gibi o kurdu. O hayatıma, kudretinden hiçbir şey kaybetmemek şartıyla kıyafetini değiştiren zalim bir hükümdar gibi girmiş, her şeyi alt üst etmiş, yakmış, yıkmış, koca evi söndürmüş ve yillarca geceleri yastığımın altında beraber uyuduktan, gündüzleri kıvrak bir su gibi önümde kayıp dolaştıktan sonra, günün birinde iki halı dengi arasında mosmor, cansız yatan bir ihtiyarın ayakları ucuna, tül gibi ince nakışlı bir yılan gömleğini bırakarak gitmişti. (2006b: 120-121)

Bu alıntıda, kahramanın hayatının ölümle çevrilmiş olmasından duyduğu kaygı betimlenmektedir. Kahramanın gençliği de ülkenin içinde bulunduğu savaş ve yokluk yıllarında, ölümün gölgesinde şekillenir:

Gençliğimde ise onu bin türlü şeklinde, fakat hep aynı yıkııı vasfinda, bütün hayata hükmederken gördüm. Vâkıa bu sefer, masal yüzünü bırakmışt; altında gizlendiği şeyin ne olduğunu, hangi maskeye büründüğün if̧̧a etmeden hüküm sürüyordu. Fakat ben bir kere onun 
terbiyesinden geçmiştim; repertuarının ve sanatının sırrını öğrenmiş bulunuyordum. Onu her gördüğ̈̈m yerde tanıdım ve dünyamızda nasıl saltanat sürdüğünü gördüm. Balkan Fecaatleri, Umumî Harbin sefaleti, yedi cephede girişilmiş savaş, hep onun, bu zalim ve kanlı meleğin üst üste takınmış olduğu çehrelerdi. (2006b: 121)

Hayatı boyunca o kadar yakından tanık olduğu kayıpların etkisiyle, artık geçtiği her yerde ve duyduğu her seste ölümü fark edebilmektedir:

Perşembe akşamları Galatasaray'dan çıkıp teyzemin evine geldiğim zaman onun, gittikçe harap ve sefil bir çehre alan bu mahallede, geçtiğim yollarda olduğu gibi, her kapının eşiğinde, her pencerenin önünde nasıl beklediğini; küçük mescitli, c1lız asmalı, yıkık çeşmeli, geceleri yalnızlığını bir hava gazı lambasının ancak ürpertebildiği sokaklarda nasıl dolaştığını; Faust'un gözlerini kör eden tasa gibi en ince delikten nasıl içerilere doğru süzüldüğünü görüyordum. Teyzemin daima biraz daha solgunlaşan yüzünde kocasının gittikçe küçülen omuzlarında, torunları Hacer'in bakışlarında hep o vardı. Geceleyin sokaktan geçen bekçinin ayak sesi ve taşlarda saati sayan sopası onu söylüyor, sisli gece yarılarında Haliç'e giren vapurların acı çı̆̆lıkları onu yayıyordu. Bunun gibi, akşam üstleri eski İstanbul sokaklarında öteberi satan satıcıların sesleri de onun türküleriydi. (2006b: 121)

İstanbul'da ölümle ilk karşılaşması, teyzesinin kızı Hacer'in veremden hayatını kaybetmesidir. Hemen arkasından da eniştesi Birinci Dünya Savaşı'nda şehit olur. Savaşın ikinci senesinde kahraman da orduya katılır ve birkaç cephede savaşın içinde bulunur. Burada da ölüm onu her yanıyla sarar:

Ölüm dört bir tarafımızdaydı; bazen koynumuza sokuluyor, derilerimiz birbirine dokunuyordu ve hemen daima, hiç olmazsa göz göze bakışıorduk. Bununla beraber korkmuyordum. Bu haşin, zalim, ah ve iniltili kanlı ölümü; insanı bir lahzada bir kemik ve et yığını haline getiren, yahut genç ve dinç bir vücudu toprakta ancak kımıldanabilen bir mahlûk, renksiz bir yığın, çarpık ve eksik bir mevcut yapan bu ölümü öbürlerine tercih ediyordum. Onu herkesle beraber görüyor, takip ediyor, çıkardığı seslerden geçtiği tarafi, yıktı̆̆ı, kasıp kavurduğu yeri bulabiliyordum. (2006b: 122)

Kahraman, savaşta aldığı yaralar nedeniyle İstanbul'da bir hastaneye kaldırılır. Bacağının biri sakat kalacak, ayaklarında ve göğsünde savaşın izlerini ömür boyunca taşıyacaktır; lakin "[o] kadar büyük şeylerden, muhteşem ümitlerden artakalmış olmanın, kendi kendisini bir rüyanın artı̆̆ hüzünle ölmüş olmayı tercih” (2006b: 123) edecektir. Buna rağmen hastaneden çıkınca hayat ona eski ümitlerini ve heyecanlarını tekrar sunar:

Binlerce defa hayatın ve ölümün çemberinden geçtikten sonra, beklediği ve hasretini çektiği mutlak sükûn yerine kendisini tekrar dünyada, tanınmış ve sevilmiş şeylerin ortasında gören ve ümidin, sstırabın, mâlik 
olmak emelinin, kaybetmek korkusunun bin türlü arzu ve ihtirasın, yeniden ve bütün iradesine rağmen, içinde bir hattıüstüva nebatı gibi büyüdüğünü, bir kovan gibi uğuldadığını, kanını kırbaçladığını, adalelerinin gerildiğini, nabzının ritmini idare ettiğini hisseden ve bu hisle beraber bu tecrübenin sonuna kadar yahut bir sonsuzluğu kadar böyle devam edeceği şuuru kendisinde büyüyen bir Budiste benziyordum... (2006b: 123)

Her ne kadar hayat ona tutunacak ümitler verse de, ülke dört senelik bir savaştan sonra fakir ve perişandır. Her köşede acı, 1stırap, korku ve bekleyiş vardır: "Ölüm, acayip ve girift bir sarmaşık gibi, bu insanların etrafında dolaşıyor, onları birbirine kenetliyor, tek bir kütle gibi yoğuruyordu. Onun dal ve budaklarında bu endişe ile dolu, solgun ve ömürlerinin faciasına bir anda uyanmış bu çehreler, küçük, zayıf ışıklı kandiller gibi parlıyorlardır" (2006b: 124-125). Hikâyenin tamamına hâkim olan ölüm teması, kahramanın Zeynep adlı bir kadına âşık olmasıyla bir anda değişir. Artık "gür hayat" onda "kendi şarkısını" söylemeye başlar. Eski musiki sayesinde tanıdığg Yümnü Beyin aracılı̆̆ıyla iki ay içinde Zeynep'le evlenir. Hayat onun için artık düzene girmiştir ama bu saadet bir sene kadar sürer. Kahramanın çocukluğundan gelen ve ölümlerle şekillenmiş kaybetme korkusu ortaya çıkar. Çocukluğunun bütün tanıdıklarını öldüren yılan rüyalarında karşısına çıkar. Zeynep’i kaybetme korkusuyla artık uyuyamaz hale gelir ve bir gece siyah yılanı karısının boynuna dolanmış bulur. Her ne kadar kadını kurtarmak için yılana saldırsa da karısının çığlıklarıyla kendisine gelir. Ev halkının odaya doluşmasıyla anlar ki yılan olarak gördüğü şey aslında karısının saçlarıdır. Hemen evden kaçarak uzaklaşır. Üç gün sonra bir tanıdıklarının evinde kahramanı bulan karısı onu affettiğini, çocukluk ve gençliğinde neler yaşadığını bildiğini söyler; ancak aralarına giren yılan/ölüm nedeniyle ağlayarak ayrılmak zorunda kalırlar. İçinde bulunduğu istırabın etkisiyle sağlığı gittikçe bozulan kahraman kendisini bir hastanede bulur. Burası hikâyenin başladığı mekândır. Doktorlara göre hastalığ 1 ciddidir ama o hastalığından ölmeyeceğini düşünür:

Fakat ben biliyorum ki, onunla ölmeyeceğim. Beni bekleyen bir başka ölüm var. Bu satırları yazarken bile onu bekliyorum, onun siyah müselles başının aralıktan görünmesini, akar sular gibi kıvrak vücudunun boynumun etrafina dolanmasını bekliyorum. Ve biliyorum ki bir gün o gelecek, bu ağır, kasvetli, her an hâtıraların hücumuyla delik deşik maceraya, bu karanlık hikâyeye siyah, kaypak külçesiyle bir son çekecek... (2006b: 139)

\section{Teşbih Kaynaklı Ölüm İmgeleri}

Her dilde anlamı canlı kılmak, güçlendirmek veya derinleştirmek için kullanılan yöntemlerden biri benzetme sanatıdır. Osmanlıca "teşbih", İngilizce 
“simile” karşılığ̣1 olan benzetme, “[b]ir nesnenin niteliğini, bir eylemin özelliğini daha iyi anlatabilmek, canlandırabilmek için bir başka nesneden, bir başka eylemden yararlanarak, onu anımsatma yoluyla gerçekleşir” (Aksan 1998: 61). Şiirin başlıca yapı taşlarından olmasının yanında benzetmeler, sözcüklerin yeni anlam yükleri kazanmasında da etkin bir yoldur. Kazanılan bu yeni anlam değerleri şair veya yazarın kişisel kullanımına bağlı olarak öne çıkar. Tanpınar, şiirlerinde benzetmelere sıkça başvurmuştur. Bunlar içinde özellikle ölüme, yaşama ve zamanın geçiciliğine ait olanlarında, Tanpınar'ın kayg1 derecesinde ölümle hesaplaştığı ve bir yönüyle ölümlü olmanın verdiği 1stırabı duyduğu açıktır. İnsan hayatının sonlu oluşunu, bireysel bir tavır olarak ölüme sitem ettiği "İnsanlar Arasında" adlı şiirinde "kader uçurumuna" benzetmektedir. Kaplan’a göre Tanpınar, "duyu ve duygularıyla bu dünyaya sımsıkı bağ $1_{1}[\mathrm{~d} ı r]$ ” ve bu şiirinde "ölüm, bütün insanlar gibi onu da varlık ötesi yahut varlık dışı hayal ve düşüncelere sevketmiştir” (2001: 142). Tanpınar'ın özlediği, istediği ebedî var olmaktır: "Kolay mı kader uçurumuna atılmak" (2009b: 94). Tanpınar'da ölüm bir uçurumdur çünkü insanın mutluluğunu bozan ölüm korkusu, yaşamın kıyısında bulunmaktadır. Şair uçurum imgesini, "Musiki" adlı şiirinde de kullanmıştır. İnsanların kervana, kervanın da bir kuşa benzetildiği bu şiirde, yolculuk meçhule/ölüme doğrudur: "Bir altın uçurum derinleşmede/Ve meçhule doğru süzüldü kervan” (2009b: 43).

Tanpınar, hocası Yahya Kemal'in “Sessiz Gemi” adlı şiirinden esinlenerek yazdığı "Rıhtımda Uyuyan Gemi”de, ölümü sembolik değeri bakımından gemi imgesi çerçevesinde kurmuş ve "güzel yolculuğga" benzetmiştir. Kaplan’a göre bu şiirde Tanpınar, "gidip de gelmeyenlerin, beyhude bekleyenlerin"; "yani ölümün korkusunu” (2001: 84) duymaktadır: "Nolur bir sabah saati/Çağırsa bizi sonsuzluk/Birden demir alsa gemi/Başlasa güzel yolculuk" (2009b: 39). Yine aynı şiirde ölüm, uykuya benzetilmektedir: "Ve şafak serinliği/İçinde uykuya dalsak” (2009b: 39). Ölümün uykuya benzetildiği bir diğer şiir ise "Bursa'da Zaman"dır. Tanpınar, tarihi ve kültürel dokusundan etkilendiği Bursa'dan bahsederken, "İsterdim bu eski yerde seninle/Baş başa uyumak son uykumuzu/Bu hayal içinde... Ve ufkumuzu/Çepeçevre kaplasın bu ziya, bu renk,/Havayı dolduran uhrevî ahenk./Bir ilâh uykusu olur elbette/Ölüm bu tılsımlı ebediyette,/Belki de rüyası büyük cetlerin” (2009b: 51) diyerek bir rüya halinde ölümü düşünmektedir. Yazara sonsuz/ölümsüz olmanın tılsımlı rüyasını veren Bursa, “ölüm” denen "uyku”ya dalmak isteyeceği tek yerdir.

Tanpınar'ın şiirlerinde bahar sabahı, sükût ve gece kelimeleri çok sık tekrar eder. Bunların bulunduğu şiirlerde, şairin hayat karşısında hiçlik duygusuna kapıldığ1 görülmektedir. Güzel olanın karşısında her zaman ölüm yani "eski korku" vardır. Tanpınar, "Defne Dalı" başlıklı şiirinde hayata 1stırap dolu bir “ümit kapısı” olarak bakmaktadır. İnsanın mutsuzluğuna sebep bu 1stıraba 
çare olarak da ölümü göstermektedir: "Ne çıkar, sonu bir neşe ve hüzün,/ Açılmış bir kapı ümit boşluğa,/Ölüm şifasıdır her üzüntünün,/Sükût defne dalı her yorgunluğa" (2009b: 42).

Tanpınar, "Üst Üste” adını taşıyan şiirinde, "[â]nın, devamın, tekrarın mucizesi” hayat içinde yalnızlık duygusuyla sıkışıp kalmıştır. Şiirde, musiki ve sessizlik kavramlarıyla tezat unsurlar oluşturmaktadır. İnsan ise zaman ve mekânda kendisi olmaya çalı̧̧maktadır. Şiirin sonunda ise, "aydınlık geceyi yırtacak" yıldırımları yani ölümü bekleyiş vardır: "Bir zihin macerası olmuş varlık!/Bekliyor sanki/Üst üste ve âdeta sonsuz/Bekliyor bu içten aydınlık geceyi yırtacak/Yıldırımları" (2009b: 79). Kaplan'a göre bu şiirde, imgeler arasında tam bir bağ kurulamamaktadır: "[B] ütün şiire, şairin benliğini aşan, kâinatı kaplayan güzel ve ihtişamlı bir âlem içinde varlığını hissettiren çok yakın bir ölüm duygusunun hâkim olduğu söylenebilir” (2001: 150).

Tanpınar, "Selâm Olsun” başlıklı şiirinde, bu dünyaya ait tabii güzelliklere ölümün penceresinden bakmaktadır. Hayata ve tabiata olan hayranlığının ifade bulduğu bu şiirde, şair çok sevdiği bu güzelliklere uzak kalmışır. Bu durum Tanpınar'da ölüm kaygısının kuvvetle hissedildiğine işaret etmektedir; çünkü o, bu dünyaya ait olan yaşamı ve doğayı sever. Şair, "Uzak, çok uzağız şimdi 1şıktan/Çocuk sesinden, gül ve sarmaşıktan/Dönmeyen gemiler olduk açıktan/ Adımızı soran, arayan var mı?” (2009b: 28) diyerek, yaşamı uzakta kaldığı ışı̆̆a benzetmiştir. Buna koşut olarak ölüm karanlık tarafı oluşturmaktadır. Karanlık tarafa geçen insan, şiirde "dönmeyen gemi” ye benzetilmiştir. Aynı benzetmeyi şair, "gidip de gelmeyenler" şeklinde "Zaman Kırıntıları"nda tekrarlar: "Biz beyhude yere gecikenler,/Çoktan bitmiş bir yolun ucunda/Bilmiyoruz 1ssiz gecede/Ne yapar ne eder,/Gidip de gelmeyenler"(2009b: 76). "Selam O1sun" başlıklı şiirdekine benzer bir durum, "Ölü" adlı şiirde bulunmaktadır. Bu şiirde de şair, bir ölünün gözünden kendisini ifade eder: "Kabrimi gösteren taş parçasından/ Yıllarla silinmiş olsa da adım/Bir zaman, ey yolcu, ben de yaşadım./Çılgın heveslerim vardı benim de" (2009b: 113). Tanpınar'ın unutulma korkusu bu şiirde de karşımıza çıkar; çünkü o ölümsüzlüğü, adının anılmasında bulacağını düşünmektedir. Sonuç olarak ölüm "bir avuç toprak" olmaktır: "Ve bir avuç toprak oldum en sonu" (2009b: 113).

Tanpınar günlüklerinde "Eşik" başlıklı şiirini şöyle yorumlar: "İdeal ile ölümün mutlakla aynıyeti. Hâl yoktur. Geleceğe geçmeye hazır bir eşik vardır, bundan öbürüne bir kamaşma içinde geçilir. Bu kamaşma bir yığın hülyalardır, vizyonlar ve tahatturlardır. Ve ben bu daima yenileşen eşikteyim" (Enginün, Kerman 2008: 251). Bu şiirde, ölümün "mutlak varlığının trajedisi”ni anlatmaya çalışmıştır. "El ele bir oyun bugün ve yarın" (2009b: 64) denilerek hayat bir oyuna benzetilirken, "Rabbim bu sonsuzluk ve onun tadı" (2009b: 66) dizesiyle de ölüm, sonsuzluk olarak ifade edilmiştir. Bu ifadede "son- 
suzluğun tadı" tamlaması yapılarak deyim aktarması yoluyla ölüme dair bir somutlama da yapıldı̆̆ı görülür. Tanpınar'ın "Karışan Saatler İçinde” adlı şiirinde ise "yolculuk" imgesi karşımıza "yaşam" olarak çıkmaktadır. Bu şiirde zamanın akışıyla hayatın devamlılığı arasında bağ kurulmaktadır: "Bir yıldız kervanı gibi haftalar, aylar/Hep aynı hayalin peşinde bu yolculuk”(2009b: 48).

\section{Teşhis Yapılı Ölüm İmgeleri}

Organ ve vücut bölümlerine ilişkin adlandırmalar doğadaki nesnelere aktarılarak dildeki sözcüklere yeni anlamlar kazandırıldığı görülmektedir. Bu tutumla kavramlar, ilişki, benzerlik veya yakınlık yönünden başka bir kavramla anlatılmaya çalışılır ve yeni anlamlarıyla dile yerleşerek kalıplaşırlar. Bu şekilde oluşan, ancak yazar veya şairin kendi kullanımıyla sınırlı kaldığı için kalıplaşmayan aktarmalardan biri olan kişileştirme sanatını Aksan şu şekilde tanımlar: "İnsandan doğaya aktarmanın bir türü, insana ait fiziksel ve ruhsal özelliklerin doğadaki varlıklara aktarılmasıyla gerçekleşir. Özellikle yazın ve şiir dilinde görülen bu tür, doğadaki varlıkları bir bakıma kişileştirdiği için kişileştirme (personification) adıyla anılır” (1998: 65). Kişileştirmeye, özellikle ölüme dair kişileştirme sanatına, Tanpınar'ın şiirlerinde fazlaca rastlanmaz. "Bir Gül Tazeliğì" adlı şiirinde, "Ayrılmayan kader baş ucumuzdan” (2009b: 32) misrainda ölümlü olma durumu, insanın hasta yatağının ucunda bekleyen refakatçiye benzetilmiştir. Bu da gösteriyor ki hayat aslında ölümle yan yana durmaktadır ve ölüm, son sözü söylemek için beklemektedir.

Tanpınar'ın üzerinde yıllarca çalıştığı ama tamamlamayı başaramadığı "Eşik" başlıklı şiirinde, ölüm sevgili olarak kişileştirilmiştir: "Geceyle ölümdür asıl sevgili/Bu ikiz aynada toplanır yollar./Karanlık yaratır, ölüm tamamlar/Kaçalım seninle biz de geceye/Ölümün kardeşi saf düşünceye.../Yeter büyüsüne aldandığımı/Güneşin...” (2009b: 67). Bu şiirde, “ölümün kardeşi” olan gece ifadesiyle ilk mısrada başvurulan kişileştirme tamamlanır. Geceyle ölümün benzerliği, "güneş" kelimesinin de yaşamla bir benzetme ilgisi uyandırdığını düşündürmektedir. Ölümün bir insan gibi düşünülmesi Beş Şebir'de şu şekilde karşımıza çıkar: "Ölüm muhayyilemizdeki çehresini değiştirir, 'Ben hayatın susan ve değişmeyen kardeşiyim. Vazifesini hakkıyla yapan fâninin alnına bir sükûn ve sükûnet çelengi gibi uzanırım..' diye konuşur” (2006a: 95-96). Yukarıda incelenen "gemi” imgesinde ölüm bir gemiye benzetilmektedir. Bu açıdan bakıldığıında "uyumak" eylemini gerçekleştiren gemi, ölümdür: "Rıhtımda uyuyan gemi/Hatırladın mı engini” (2009b: 39). Ayrıca geminin insana özgü hatırlamak eylemini gerçekleştiriyor olması da kişileştirme sanatının kullanılmasına örnektir. Yine bu şiirinde ölüm, sonsuzluk kavramıyla bütünleştirilmiştir. Sonsuzluğun, yani ölümün şairi çağırıyor olması da insana dair bir özelliktir: "Nolur bir sabah saati/Çağırsa bizi sonsuzluk" (2009b: 39). 
Tanpınar, "Avare İlhamlar" ve "Eşik" başlıkl şiirlerinde, "cellât" imgesini kullanarak ölüm temasıyla bağ kurmaktadır. Şair, bu hayatta mahpustur ve geçen her saat işkence yapan bir insan gibi düşünülmüştür. Bunun yanı sıra, günler de onu ölüme götüren cellâdıdır: "Saatler işkence, günler cellâdım" (2009b: 124)، "Avare İlhamlar"da ise, kader gibi soyut bir kavram ölümle ilişkilendirilerek cellâda benzetilmiştir: "Kader celladına/Sessiz uzat boynunu;/Acıma ne kendine ne de gelecek günlerine/Yalnız bir düşünceye yum gözlerini/Son darbe inmeden evvel, en son anda./Bir çiçek, bir kuş, bir tebessüm ol,/Düşüncen kurtarsın seni senden,/Bil! Biraz sonra/Ebediyet senindir/Senden uzak olan her şey" (2009b: 77). Zamanın bir mezar kazıcısı olarak kişileştirildiği "Zaman Kırıntıları"nda Tanpınar, günden güne ölüme yaklaşmanın verdiği sıkıntıyı dile getirmektedir: "Ben zamanı gördüm,/İçimde ve dışımda sessiz çalışıordu,/Bir mezar böyle kazılırdı ancak" (2009b: 72). Şair, içinde "sessiz çalışan" zaman sitemini, "ancak" sözcüğüyle dile getirmektedir; çünkü 1950'de kırk dokuz yaşındayken yazdığı bu şiir, ölümden endişelenmeye başladığı zamana denk gelmektedir.

\section{Sonuç}

Felsefî alanda birçok farklı tanımı bulunan ölüm, Tanpınar'ın eserlerinde derinlemesine işlediği konuların başında gelmektedir. Özellikle yazdığı günlükler dikkate alınacak olursa, yaşamının son yıllarında ölüm karşısında belirgin bir kaygı duyduğu anlaşılmaktadır. Bunun temelinde Tanpınar'ın kendi içinde oluşturduğu ikiliğin sonuçlarını görmek mümkündür. Şair, dış olarak tanımladığı yaşamında aslında olmak istediği kişi değildir ve iç dünyasında kurguladığı ben'inin çatışmasını yaşamaktadır. Bu durum, hayatını istediği gibi yaşayamamak, kendi kimliğini oluşturamamak, maddî imkânsızlıklar ve hayatta bir şeyleri hep yarım bırakma endişesi olarak ifade bulmaktadır.

Tanpınar, edebî eserlerinde kendi mazisiyle koşut birçok olayı işlemiş ve tanık olduğu ölümlerin izini sürmüştür. Gerçek hayattaki bu ölümlerin onun zihninde açtığı yaraları, roman ve hikâyelerinde kahramanları, şiirlerinde sembolleri aracilığ ile işlemiştir. Tanpınar, ölüm ve yaşamı birbirini tamamlayan, biri diğerinin içinde var olabilen iki öğe olarak görmektedir. Hatta bu iki durum arasında geçişi perde motifiyle simgelemiştir. Perdenin öbür tarafında yani ölümde, insanın var olabileceğini düşünerek ölümün aslında bir son olmadığı kanısına ulaşmıştır. Elbette Tanpınar da, insan doğasının gereği olarak ölümü istememektedir ama ölümsüz bir hayat süremeyeceğinin de bilincindedir. Sanatçı kişiliğinin bir yansıması olarak ölümsüzlüğü, ortaya koyduğu eserlerin kalıc1lığına ve böylece isminin unutulmamasına bağlamıştır.

Tanpınar'ın eserlerindeki ölüm teması ve motiflerinin tespit edildiği bu çalışmada, şairin yaşadığ dönem ve tanık olduğu olaylara ilişkin gözlemleri ile 
mistik bir anlayışı çağrıştıran Doğu sentezi, onun gözünde ölümü farklı bir noktaya taşımıştır. Buna göre ölüm, yaşamı anlamlı kılan bir anahtardır ve sanatsal duyarlılık sayesinde anlaşılır kılınan ölüm, yaşamı anlamlı kılmaya yarayan bir araçtır. Nasıl ki ölüm engellenemiyorsa, yaşamdan en üst düzeyde haz almak gerekir. Ne var ki Tanpınar, düşünce düzeyinde eriştiği ve bütün eserlerine yansıttığı bu anlayışı pratiğe dökememiş; parasızlık, başkaları tarafından anlaşılamadığı kanısı, bitmemiş eserlerinin yarattığı umutsuzluk, ikilemli ruh dünyası gibi nedenlerle bu hazzı yaşayamamıştır.

\section{Kaynaklar}

Aksan, Doğan (1998). Anlambilim, Ankara: Engin Yayınevi.

Balcı, Yunus (2008). Tanpınar Trajik Bir Şair ve Şiiri, İstanbul: 3F Yayınevi.

Bauman, Zygmunt (2000). Ölümlülük, Ölümsüzlük ve Diğer Hayat Stratejileri, Çev. Nurgül Demirdöven, İstanbul: Ayrıntı Yayınları.

Bayrak, Özcan (2008). "Ölümün Gizemi ve Simgesel Bir Unsur Olarak Yahya Kemal ve Tanpınar'ın Şiirine Yansıması”, Akpınar 13.

Beyatl, Yahya Kemal (2011). Kendi Gök Kubbemiz, İstanbul: İstanbul Fetih Cemiyeti Yayınları.

Campbell, Joseph ve Bill Moyers (2010). Mitolojinin Gücü, Çev. Zeynep Yaman, İstanbul: MediaCat Kitaplar1.

Çonoğlu, Salim (2007). Cumburiyet Dönemi Türk Şiirinde Ölüm, Ankara: Akçağ Yayınlar1.

Enginün, İnci ve Zeynep Kerman (2008). Günlüklerin Işı̆̆ında Tanpınar'la Başbaşa, İstanbul: Dergâh Yayınları.

Gilson, Paul (1986). Batı Şiirinden Çeviriler, Çev. Sezai Karakoç, İstanbul: Diriliş Yayınları.

Günay, Ünver ve Harun Güngör (2003). Başlangıçlarından Günümüze Türklerin Dini Taribi, İstanbul: Rağbet Yayınları.

İşeri, Kamil ve Sercan Demirgüneş (2008). "Sessiz Gemi Şiirinin Anlambilimsel/ Göstergebilimsel İncelenmesi”, Türkoloji Araștırmaları Dergisi 3/4.

Jung, Carl Gustav (1992). Ölüm ve Ruh, Ölümün Anlamı, Çev. Doğan Özkan, İstanbul: Merkuri Yayınları.

Kaplan, Mehmet (2001). Tanpınar’in Şiir Dünyası, İstanbul: Dergâh Yayınları.

Kocatürk, Saadettin (1981). "Mevlânâ’da Ölüm Kavramı”, Millî Kültür 8.

Kolcu, Ali İhsan (2002). Zamana Düssen Çı̆̆lık: Tanpınar'in Şiirinin Epistemolojik Temelleri E̋ Tanpınar'ın Şiir Estetiği, Ankara: Akçă̆ Yayınları.

Malpas, Feff ve Robert C. Solomon (2006). Ölüm ve Felsefe, Çev. Nur Küçük, İstanbul: İthaki Yayınları.

Maurois, Andrè (1961). Yaşamak Sanatı Hayatın Küçük Felsefesi, İstanbul: Kanaat Yayınlar1.

Okay, Orhan (2012). Bir Hülya Adamının Romanı, İstanbul: Dergâh Yayınları. 
Ömer Hayyam (2009). Dörtlükler, Çev. Sabahattin Eyüboğlu, İstanbul: Türkiye İş Bankası Kültür Yayınları.

Parlatır, İsmail (1998). Türkçe Sözlük, Ankara: Türk Dil Kurumu Yayınları.

Tanpınar, Ahmet Hamdi (1998). Edebiyat Üzerine Makaleler, Haz. Zeynep Kerman, İstanbul: Dergâh Yayınları.

(1999). Sahnenin Dışındakiler, İstanbul: Dergâh Yayınları. (2000). Yaşadığım Gibi, Dergâh Yayınları, İstanbul. (2002). Huzur, İstanbul: Dergâh Yayınları. (2006a). Beş Şehir, İstanbul: Dergâh Yayınları. (2006b). Hikâyeler, İstanbul: Dergâh Yayınları. (2009a). Aydaki Kadın, İstanbul: Dergâh Yayınları. (2009b). Bütün Şiirleri, Haz. İnci Enginün, İstanbul: Dergâh Yayınları.

Yalom, Irvin D. (2008). Güneşe Bakmak Ölümle Yüzleşmek, Çev. Zeliha İyidoğan Babayiğit, İstanbul: Kabalcı Yayınları. 


\section{ABSTRACT \\ Images of Death in Ahmet Hamdi Tanpınar's Poetics}

This study explores literary symbols employed in Ahmet Hamdi Tanpinar's works which reflect his thoughts on death. According to Tanpinar, death is a philosophical question that reflects the tragic side of life, a question that has a deep impact on his thoughts. His realization of his mortality as an artist on the one hand, and his search for immortality through his body of work, history, society, and culture that he is in, are one of the main points of conflict in his works. An analysis of Tanpinar's works reveals that the ideas of death and mortality are at the core of his process of writing. As a result he uses, consciously or subconsciously, symbols related to death. The fact that death does not have a clear description leads one to give it a different meaning. Tanpinar, as a human being and as an artist, as well as a member of the society, interpreted the subject in his own way and reflected upon these in his works. These symbols represent themselves as synonyms or in similar wording in his various works. This article explores main images employed in Tanpinar's works.

Keywords: Turkish poetry, Ahmet Hamdi Tanpinar, death, image, metaphor 
